\title{
An Integrated Approach to Evaluate Benefits and Costs of Wastewater and Solid Waste Management to Improve the Living Environment: The Citarum River in West Java, Indonesia
}

\author{
S. M. Kerstens' ${ }^{1}$ G. Hutton², I. Firmansyah'3 ${ }^{3}$ I. Leusbrock ${ }^{4}$, G. Zeeman ${ }^{3}$ \\ ${ }^{1}$ Royal HaskoningDHV, Amersfoort, The Netherlands \\ ${ }^{2}$ UNICEF, New York, USA \\ ${ }^{3}$ Sub-Department of Environmental Technology, Wageningen University, Wageningen, The Netherlands \\ ${ }^{4}$ AEE INTEC, Gleisdorf, Austria \\ Email: sjoerd.kerstens@rhdhv.com, ghutton@unicef.org, indra.firmansyah@wur.nl, i.leusbrock@aee.at, grietje.zeeman@wur.nl
}

How to cite this paper: Kerstens, S.M., Hutton, G., Firmansyah, I., Leusbrock, I. and Zeeman, G. (2016) An Integrated Approach to Evaluate Benefits and Costs of Wastewater and Solid Waste Management to Improve the Living Environment: The Citarum River in West Java, Indonesia. Journal of Environmental Protection, 7, 1439-1465. http://dx.doi.org/10.4236/jep.2016.711122

Received: July 26, 2016

Accepted: October 8, 2016

Published: October 11, 2016

Copyright $\odot 2016$ by authors and Scientific Research Publishing Inc. This work is licensed under the Creative Commons Attribution International License (CC BY 4.0).

http://creativecommons.org/licenses/by/4.0/

\section{Abstract}

Absence of wastewater and solid waste facilities impacts the quality of life of many people in developing countries. Implementation of these facilities will benefit public health, water quality, livelihoods and property value. Additional benefits may result from the potential recovery of valuable resources from wastewater and solid waste, such as compost, energy, phosphorus, plastics and paper. Improving water quality through implementation of wastewater and solid waste interventions requires, among others, an analysis of i) sources of pollution, ii) mitigating measures and resource recovery potentials and their effect on water quality and health, and iii) benefits and costs of interventions. We present an integrated approach to evaluate costs and benefits of domestic and industrial wastewater and solid waste interventions. To support a policy maker in formulating a cost- and environmentally effective approach, we quantified the impact of these interventions on 1) water quality improvement, 2) resource recovery potential, and 3) monetized benefits versus costs. The integration of technical, hydrological, agronomical and socio-economic elements to derive these three tangible outputs in a joint approach is a novelty. The approach is demonstrated using the heavily polluted Indonesian Upper Citarum River in the Bandung region. Domestic interventions, applying simple (anaerobic filter) technologies, were economically most attractive with a benefit cost ratio (BCR) of 3.2, but could not reach target water quality standards. To approach the target water quality, both advanced domestic (nutrient removal systems) and industrial wastewater treatment interventions were required, leading to a BCR of 2 . We showed that benefits from selling recovered resources represent here an additional driver for improving water quality 
and outweigh the additional costs for resource recovery facilities. While included benefits captured some of the major items, these may have been undervalued. Based on these findings, water quality interventions justify their costs and are socially and economically beneficial.

\section{Keywords}

Sanitation, Water Quality Modeling, Economic Cost Benefit Analysis,

Resource Recovery, Asia, Indonesia

\section{Introduction}

Nearly $40 \%$ of the population in developing countries lacks access to improved sanitation facilities [1], while an estimated $90 \%$ of all wastewater in developing countries is discharged untreated directly into rivers, lakes or the oceans [2]. Although access to improved sanitation facilities in South East Asia has reached 72\%, Indonesia is lagging behind with only $61 \%$ [1]. Moreover, Indonesia, like other developing countries, largely lacks solid waste management services and suffers from uncontrolled discharge of industrial wastewater [3] [4]. The absence of domestic and industrial wastewater and solid waste facilities is associated with a number of impacts.

First, discharge of untreated sewage can lead to adverse health effects on individuals [5]. Health conditions can be improved by wastewater and hygiene interventions [6] [7]. Reference [8] showed that E. coli concentrations in canals could be substantially reduced $(\sim 4 \log )$ by sewage collection and treatment. On-site sanitation (e.g. pit latrines as commonly applied in Indonesia) in combination with shallow ground water sources and high population density may also impact public health [9] [10].

Second, discharge of untreated wastewater increases nitrogen $(\mathrm{N})$, phosphorus $(\mathrm{P})$ and organic pollutants (Chemical oxygen demand (COD) and Biological Oxygen Demand (BOD)) loads to water bodies. This may result in eutrophication and low oxygen levels in waters, thus impacting ecosystem functioning [11]-[14]. Domestic pollution depends on living conditions and type of residential areas [15]-[17]. There is also a positive correlation between imperviousness and urban density on pollution gradients in receiving water bodies [18]. A range of wastewater and solid waste systems exists and their feasibility can be linked to residential features [19] (see Online Supplementary Information (OSI), Section 1). Wastewater and solid waste systems range from conventional (e.g. solid waste landfilling) to those that reduce, reuse and recycle (3R) solid waste components or recover resources from wastewater [19] [20]. Industrial wastewater discharge may also contribute significantly to water pollution [14]. Applicable treatment technologies depend on type of industry, biodegradability, toxicity, robustness, effluent standards or reuse requirements [21] [22]. Water quality is further affected by agricultural activities, as a result of fertilizer use, aquaculture and livestock emissions [11] [23]. 
Third, the value of recoverable resources from wastewater and solid waste, such as energy, water, organics, nutrients, plastic and paper is frequently neglected, whereas the sale of recovered resources can assure long-term operational and financial sustainability [24]-[28]. The potential demand for recovered resources depends on agricultural activities and possibilities to replace conventional production processes using virgin materials by processes using recyclables (paper and plastics) [29].

Finally, the absence of wastewater and solid waste facilities may accrue socio-economic impacts, such as travel and waiting time for community or public toilet facilities, loss of social capital and equity and decreased property values [14] [30]-[33].

Thus, implementation of wastewater and solid waste interventions benefits public health, the environment, resource conservation, the economy and people's welfare. However, given that implementation of interventions involves costs in the form of investments, operation and maintenance of the facilities, policy makers need to understand the outcomes (benefits) of major actions in relation to their costs [34]. The Benefit Cost Ratio (BCR) describes benefits of intervention relative to its costs. Given that benefits may require a long time to manifest and planned infrastructure are designed for long lifetimes, benefit-cost analysis should use a time horizon of at least 20 years [35]. A demonstrated BCR of one or more-indicating a return on investment of at least 1.0 given the discount rate used-can feed into advocacy efforts to raise funding from governments and households, and can convince the private sector to invest [32].

Individual cause-effect relationships to evaluate the costs and benefits to improve water quality have been established, such as: 1) the effect of pollution load on the quality of receiving water [13] [18], 2) the effect of sanitation on public health improvement and reduced discharged pollution loads [11] [36],3) economic losses as a result of poor sanitation [32], and 4) technical and financial feasibility of wastewater and solid waste technologies [19]. However, no integrated framework exists in the scientific literature that quantifies the effect of applicable wastewater and solid waste interventions on 1) water quality, 2) resource recovery potential, and 3) monetized benefits and costs. This paper therefore proposes to use a combination of methods that describe these individual cause-effect relationships, and synthesize them to produce these three tangible outputs. This multi-methods approach allows policy makers to make well-informed choices in wastewater and solid waste planning.

The developed approach can be used on any river basin or delta. In this paper, the Upper Citarum River in West Java (Indonesia) is used as a case study because of its very low water quality combined with its impact on the life of millions of people downstream (see Figure 1 and OSI Section 2).

\section{Materials and Methods}

To assess the impact of wastewater and solid waste interventions on water quality and estimate resource recovery and economic returns, the following six consecutive steps were formulated (Figure 2). In step 1 the river water quality at different locations was 


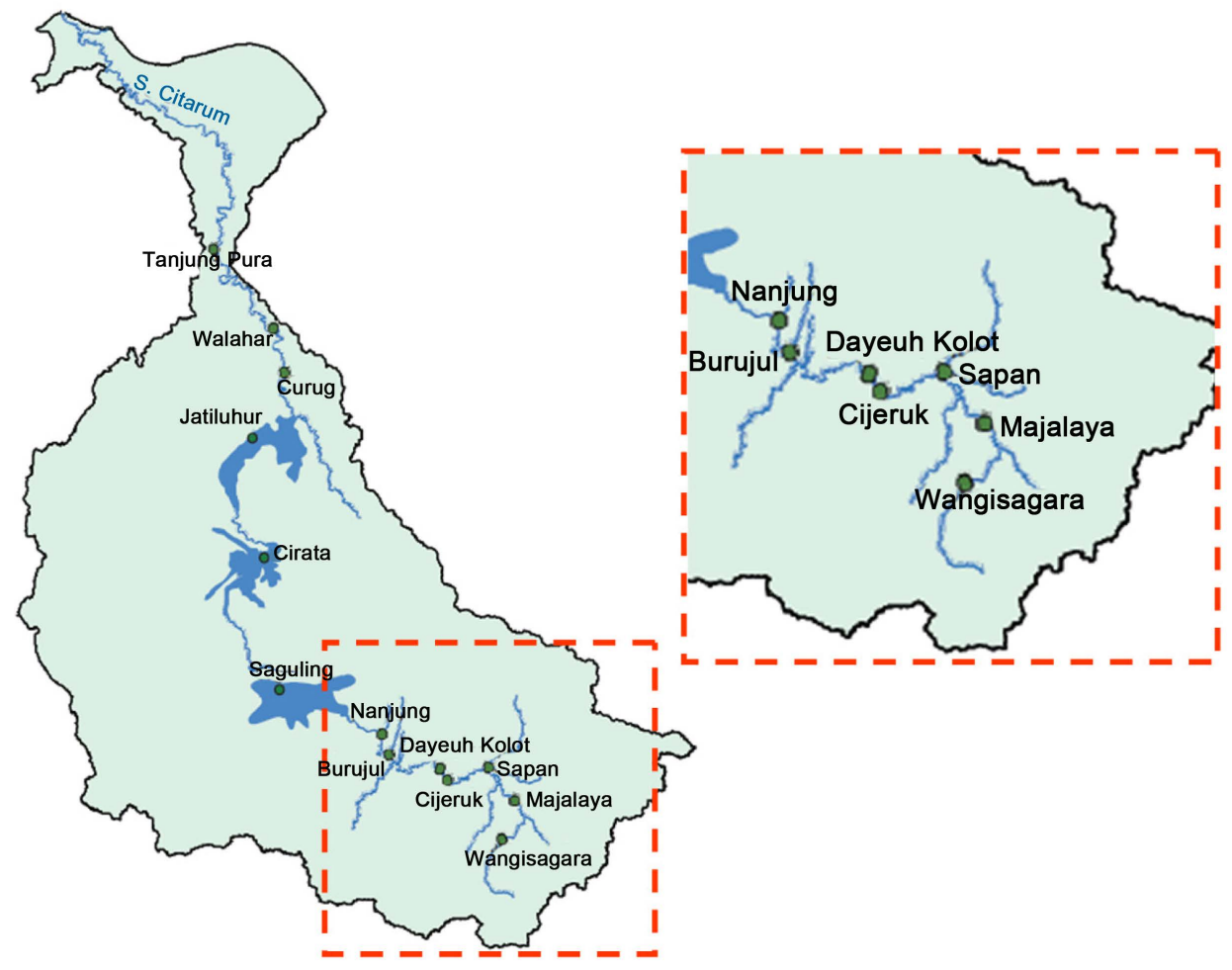

Figure 1. Location of the Upper Citarum River basin (in box) within the Citarum basin.

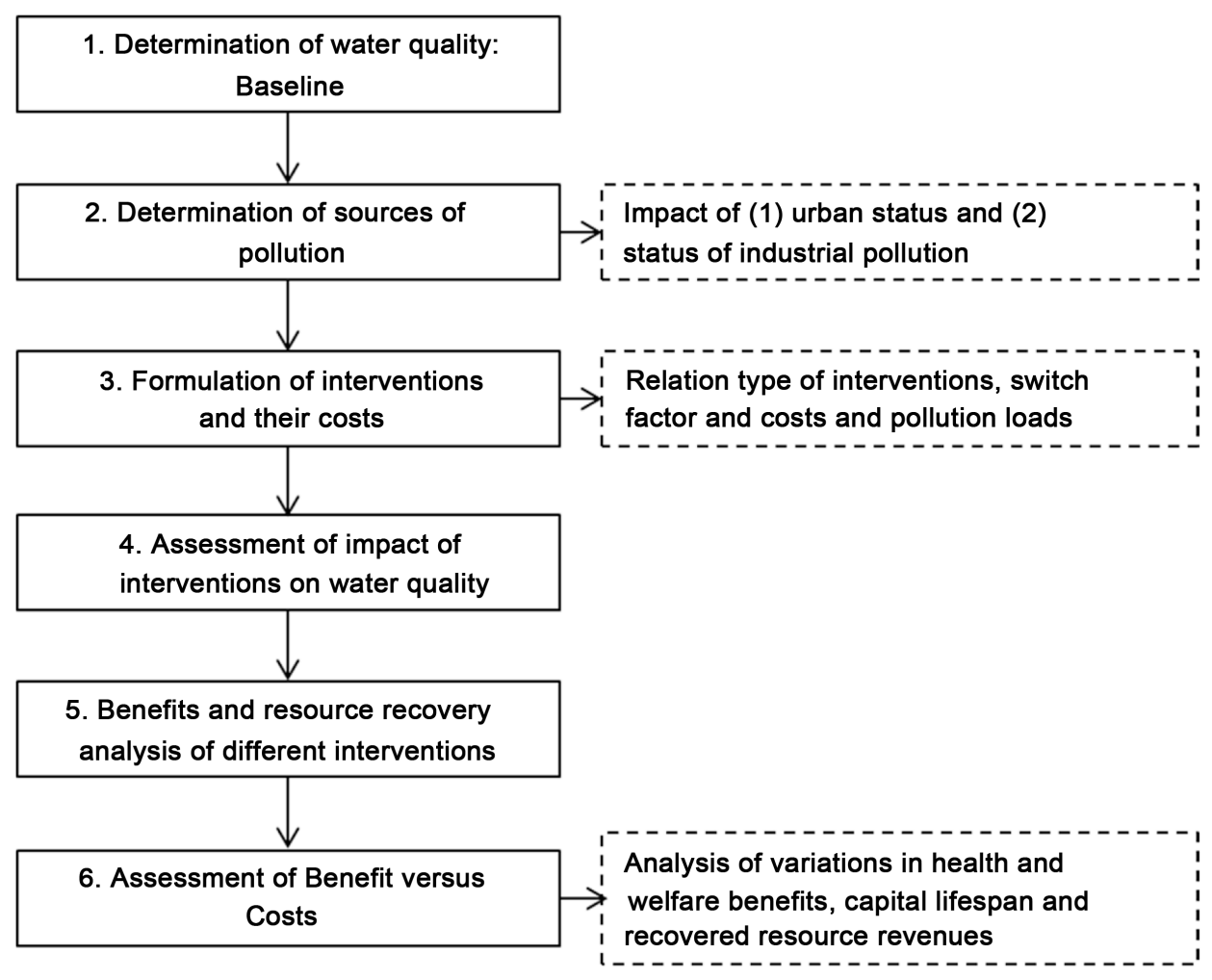

Figure 2. Approach applied to determine the BCR of interventions (Dashed blocks show activities for which a sensitivity analysis was performed). 
collected. This information was used as a baseline to determine the impact of different types of interventions. In step 2 the sources of pollution COD, BOD, N and P per sector (domestic, industrial and agricultural) were determined. An additional assessment on the relative contribution per sector was performed considering variations in the pollution load reaching the surface water with different urban areas [18] and the status of industrial pollution control [37]. In step 3 wastewater and solid waste interventions were defined and their associated costs estimated, based on [19]. The impact on pollution loads discharged to the environment and the associated costs were further analyzed by varying treatment technologies and the percent of households switching from a septic tank to a sewer system connection. In step 4 the impact of different interventions on water quality was determined using a river basin simulation software (RIBASIM) [38]. In step 5, five different benefits were monetized: health, access time, water quality, environment and revenues from resource recovery [19] [31]. In step 6 the benefits and costs were compared over a 20 year period to estimate the benefit-cost ratios. In this final step also a sensitivity analysis was performed to determine the impact of reduced health, welfare and revenues from recovered resources and of different capital lifespan on the BCR. A description of the individual steps and method for data collection is further illustrated using the Upper Citarum River as an example.

\subsection{Step 1: Determination of Water Quality in Upper Citarum River}

Water quality data for COD, BOD, N and P for the period 2001-2009 in the upper Citarum River at Wangisagara, Sapan, Cijeruk, Dayeukholot and Nanjung (Figure 1) was obtained through the West Java Regional Environmental Agency [39] [40].

\subsection{Step 2: Determination of Sources of Pollution}

Three sources of pollutions were distinguished and assessed for 2010 and 2030, being (A) Domestic, (B) Industrial and (C) Agricultural (Table 1).

\section{A. Domestic pollution:}

Domestic pollution was determined in five steps.

1. Determination of specific per person pollution loads: Domestic specific water consumption rates followed the Indonesia guidelines [16] for 6 categories of urban area: 1) metropolitan (>1 million people), 2) large town (500,000 - 1 million people), 3) medium town (100,000 - 500,000 people), 4) small town (20,000 - 100,000 people), 5 ) village (3000 - 20,000 people) and 6) rural ( $<3000$ people). An $80 \%$ return factor was used to estimate wastewater production from consumed water [41]. Metropolitan specific pollution loads were based on [19].

2. Correction of pollution load with varying types of urban status: The relation between urban category and pollution loads was reflected using the study of [17] applying a greywater pollution load decrease between urban metropolitan and rural areas of $30 \%$ of COD and $\mathrm{N}$ and $50 \%$ of $\mathrm{P}$, while for urban categories in between metropolitan and rural areas these were made relative to water consumption data (Table 1). Because of lack of detailed data, urban and rural black water pollution load rates were assumed the same. 
Table 1. Basis for applied Domestic (A), Industrial (B) and Agricultural (C) pollution reaching the surface water.

\begin{tabular}{|c|c|c|c|c|c|c|c|c|c|c|c|}
\hline \multicolumn{7}{|c|}{$\begin{array}{l}\text { A. Domestic per capita pollution } \\
\text { loads reaching surface water }\end{array}$} & \multicolumn{5}{|c|}{$\begin{array}{l}\text { B. Industrial concentrations } \\
\text { in effluent per type of industry }\end{array}$} \\
\hline \multirow{2}{*}{ Urban category } & Water use & COD & BOD & TN & $\mathrm{TP}$ & Coliform & \multirow{2}{*}{$\begin{array}{l}\text { Type of } \\
\text { industry }\end{array}$} & COD & BOD & $\mathrm{TN}$ & $\mathrm{TP}$ \\
\hline & 1/cap/d & & $g / 1$ & $/ d$ & & $1 / 100 \mathrm{ml}$ & & \multicolumn{4}{|c|}{$\mathrm{mg} / \mathrm{l}$} \\
\hline 1. Metropolitan & 190 & 82.2 & 41.1 & 12.3 & 2.1 & $1 \times 10^{8}$ & $\begin{array}{c}\text { Food \& } \\
\text { Beverage }^{\mathrm{b}}\end{array}$ & 5000 & 3000 & 80 & 30 \\
\hline 2. Large town & 170 & 81.0 & 40.5 & 12.3 & 2.0 & $1 \times 10^{8}$ & Paper $^{\mathrm{c}}$ & 4000 & 1500 & 20 & 10 \\
\hline 3. Medium town & 150 & 73.5 & 36.7 & 11.3 & 1.9 & $1 \times 10^{8}$ & Pharmaceutical $^{\mathrm{d}}$ & 5000 & 1500 & 127 & 25 \\
\hline 4. Small town & 130 & 65.3 & 32.7 & 10.2 & 1.7 & $1 \times 10^{8}$ & Rubber $^{\mathrm{d}}$ & 7340 & 4400 & 1100 & 220 \\
\hline 5. Village & 100 & 56.9 & 28.5 & 9.1 & 1.5 & $1 \times 10^{8}$ & Textile $^{e}$ & 1350 & 450 & 60 & 20 \\
\hline 6. Rural & 30 & 47.3 & 23.7 & 7.9 & 1.3 & $1 \times 10^{8}$ & Others $^{\mathrm{d}}$ & 280 & 168 & 42 & 8 \\
\hline \multicolumn{12}{|c|}{ C. Agricultural pollution loads (g/Yield.ha) ${ }^{\mathrm{d}}$} \\
\hline Type of crops & COD & & & BOD & & $\mathrm{TN}$ & $\mathrm{TP}$ & & & liform & \\
\hline Rice & 45 & & & 22.5 & & 21.5 & 6.5 & & & 0 & \\
\hline $\begin{array}{l}\text { Non-rice } \\
\text { food crops }\end{array}$ & 34 & & & 17 & & 4.6 & 0 & & & 0 & \\
\hline
\end{tabular}

a. Based on [17]-[19]; b. Data obtained by authors from Food \& Beverage (dairy, brewery) in Indonesia; c. Values depend on type of paper and pulping process and range from 1500 to over 20,000 mg/l COD [21] [48]. Applied values are based on experience of authors for Pulp and Paper South East Asia; d. Based on [47]; e. Textile industry data were determined based on actual measurements of 21 textile industries in project area [37] and verified with [21].

3. Correction of pollution reaching surface water bodies: Baseline pollution correction coefficients (included in Table 1) were based on [18] and were 100\% (metropolitan and large towns), 92\% (medium town), 83\% (small town), 74\% (village) and 65\% (rural areas). Thus, only $83 \%$ of pollution generated in a small town is expected to reach the surface water. As specific information on these coefficients was lacking for the Upper Citarum Basin, two alternative scenarios were compared, being 1) where $100 \%$ of pollution entered the surface water, and 2) where half of the baseline value entered the surface water (i.e. $50 \%$ for metropolitan and large towns, $46 \%$ for medium town, $42 \%$ for small towns, $37 \%$ for village and $33 \%$ for rural areas).

4. Determination of pollution loads reaching the surface water for 2010 and 2030: Total specific pollutions loads per location reaching the surface water were calculated applying the specific pollution loads (combining step 2 and 3 above) on population developments obtained from the Java Spatial Model (JSM). JSM shows the population development for each urban category between 2010 and 2030 [16].

5. Determination of the number of people with access to wastewater facilities in 2010: The pollution loads reaching the water bodies were corrected for interventions already in place. The 2010 wastewater access data were obtained from the statistical bureau of Indonesia (BPS) and were determined as 52\%. 490,000 people were connected to the Bojong Soang WWTP (pond systems) in Bandung [42]. 


\section{B. Industrial pollution:}

838 industries in the catchment area were categorized by location and type (Table 1) and water consumption $\left(\mathrm{m}^{3} / \mathrm{d}\right)$ in which data on ground and surface water consumption were obtained from the West Java provincial agency for Energy and Mineral Resources [43] and provincial agency for Water Resources Management [44]. Pollution loads were determined by effluent flow (using $80 \%$ return factor) and effluent concentrations (Table 1). Because reliable industrial pollution data is lacking [37], an impact analysis was performed (Table 2). A distinction is made between 1) a best case scenario, 2) a baseline scenario and 3) a worst case scenario. These scenarios vary in terms of removal efficiency and percentage of industry having a WWTP (Table 2). COD removal efficiencies in the best case followed self-reported COD removal efficiencies by industries, whereas the worst case effluent COD values followed externally measured COD removal efficiencies [37]. $\mathrm{N}$ and $\mathrm{P}$ are not measured by industries and presented values were assumed, based on [21]. Reference [45] reports that $80 \%$ of the textile industries comply with the effluent standards, whereas the environmental office in nearby Cimahi mentions 3\% [46]. Therefore, the baseline case assumes that $80 \%$ of the largest industries (consumption $>2000 \mathrm{~m}^{3} / \mathrm{d}$ ) treat their wastewater, while with decreasing water consumption this percentage decreases with a minimum of 25\% (Table 2).

\section{Agricultural pollution:}

The 2010 and 2030 water demand for irrigation was based on [16]. Pollution discharged (Table 1) for rice and non-rice crops were based on [47].

\subsection{Step 3: Formulation of Interventions and Their Costs}

\section{Domestic interventions:}

Selection of type of domestic WWT facilities (Table 3) was based on the residential features following [19]. For off-site systems three scenarios were compared to identify the effect on the surface water quality and cost:

1. Simple Technology (ST): Anaerobic filter is applied for medium centralized systems and a conventional activated sludge (CAS) for centralized systems;

2. Advanced Technology (AT): Medium central and central systems apply a CAS with additional N, P removal;

Table 2. Defined scenarios to determine the impact of industrial pollution loads by varying 1 ) removal efficiencies and 2) availability of WWTP based on size of water intake ${ }^{\mathrm{a}}$.

\begin{tabular}{lccccccccc}
\hline \multirow{2}{*}{ Scenario } & \multicolumn{3}{c}{$1 . \%$ Removal efficiency } & \multicolumn{5}{c}{ 2. \% industries with WWTP per size of water intake $\left(\mathrm{m}^{3} / \mathrm{d}\right)$} \\
\cline { 2 - 9 } & COD & BOD & TN & TP & $0-100$ & $100-500$ & $500-1000$ & $1000-2000$ & $>2000$ \\
\hline Best case & 90 & 95 & 90 & 50 & 35 & 35 & 60 & 80 & 90 \\
Baseline & 65 & 69 & 65 & 36 & 25 & 25 & 50 & 70 & 80 \\
Worst case & 40 & 42 & 40 & 22 & 15 & 15 & 40 & 60 & 70 \\
\hline
\end{tabular}

a. Table 2 shows for example that in the best case scenario, $90 \%$ of the industries with a water consumption exceeding $2000 \mathrm{~m}^{3} / \mathrm{d}$ have a WWTP and removal efficiencies are 90\% (COD), 95\% (BOD), 90\% (TN) and (50\% (TP). 
Table 3. WWT system selection based on 1) population density and 2) urban/rural category. Removal efficiencies of Simple technologies (ST), Advanced Technologies (AT) and Resource Recovery (RR) technologies for COD, BOD, TN, TP and coliforms are based on [19].

\begin{tabular}{|c|c|c|c|c|c|c|c|c|c|c|c|c|}
\hline \multirow{3}{*}{ System } & \multicolumn{2}{|c|}{ Criteria for use $\mathrm{a}^{\mathrm{a}}$} & \multicolumn{10}{|c|}{ Applied removal efficiencies per type of technology } \\
\hline & \multirow{2}{*}{$\begin{array}{l}\text { Residential } \\
\text { population } \\
\text { density }\end{array}$} & \multirow{2}{*}{ Status $2020^{\mathrm{b}}$} & \multicolumn{2}{|c|}{ COD (\%) } & \multicolumn{2}{|c|}{$\mathrm{BOD}(\%)$} & \multicolumn{2}{|c|}{$\mathrm{TN}(\%)$} & \multicolumn{2}{|c|}{ TP (\%) } & \multicolumn{2}{|c|}{ Coliforms (\%) } \\
\hline & & & ST & $\mathrm{AT} / \mathrm{RR}$ & ST & $\mathrm{AT} / \mathrm{RR}$ & ST & $\mathrm{AT} / \mathrm{RR}$ & ST & $\mathrm{AT} / \mathrm{RR}$ & ST & $\mathrm{AT} / \mathrm{RR}$ \\
\hline On-site & $<100$ & Rural/Urban & & $40^{\mathrm{a}}$ & & 45 & & 15 & & 5 & & 90 \\
\hline CBS & $>100$ & Rural & & $80^{\mathrm{a}}$ & & 85 & & 15 & & 5 & & 99 \\
\hline $\begin{array}{l}\text { Medium } \\
\text { Central }\end{array}$ & $100-250$ & Urban & 80 & 88 & 85 & 97 & 15 & 90 & 5 & 67 & 99 & 99.9 \\
\hline Central & $>250$ & Urban & 88 & & 97 & & 73 & & 29 & & 99.9 & \\
\hline
\end{tabular}

a. Current users in urban areas with a residential density between $25-100 \mathrm{pp} / \mathrm{ha}$ apply on-site systems, whereas all new development will be served by medium centralized system [50]; b. Selection criteria are formulated based on the expected population status in 2020 (mid-term).

3. Resource Recovery technology (RR): Comprising Aerobic Granular Sludge (AGS) system [49] with sludge digestion, P-recovery as struvite and composting of produced sludge. The removal efficiencies of AT and RR are the same.

Associated investment and operational costs were based on [19] (see Table S1 of the OSI Section 1). The effects on discharged pollution loads reaching the surface water and associated investment costs of a $25 \%, 50 \%$ and $75 \%$ switch of households currently applying on-sites system to an off-site system were compared.

\section{Industrial interventions:}

Three industrial wastewater treatment types were formulated based on currently applied technologies [51] (see OSI, Section 3): 1) textile wastewater using reactive dyes (typically used for traditional batik), apply a CAS and activated carbon for color removal, 2) textile wastewater using non-reactive dyes apply CAS followed by Dissolved Air Flotation (DAF), and 3) other industries apply pre-treatment (DAF) and CAS. Future effluent values should meet at least current standards [46] defined as $80 \mathrm{mg} / \mathrm{l} \mathrm{COD \text {, }}$ $20 \mathrm{mg} / \mathrm{l} \mathrm{BOD}, 10 \mathrm{mg} / \mathrm{l} \mathrm{N}$ and $10 \mathrm{mg} / \mathrm{l} \mathrm{P}$. Investment and operational costs were determined for different sizes of treatment capacities, based on available engineering cost standards (see OSI, Section 3).

\section{Municipal Solid Waste (MSW) interventions.}

Solid waste system selection interventions (Table 4) and their costs are based on [19] and distinguish home composting, landfilling and centralized and decentralized 3R application (see OSI Section 4).

\subsection{Step 4: Assessment of Impact of Interventions on Pollution Loads and Water Quality}

A generic model package (RIBASIM) for simulating the behavior of river basins under various hydrological conditions was used to simulate the effect of different interventions on water quality development in the Upper Citarum River [38] [52]. Based on pollution loads produced in each defined catchment area and resulting water flows 
Table 4. MSW system selection for Indonesia as a function of density, urban/rural status [50].

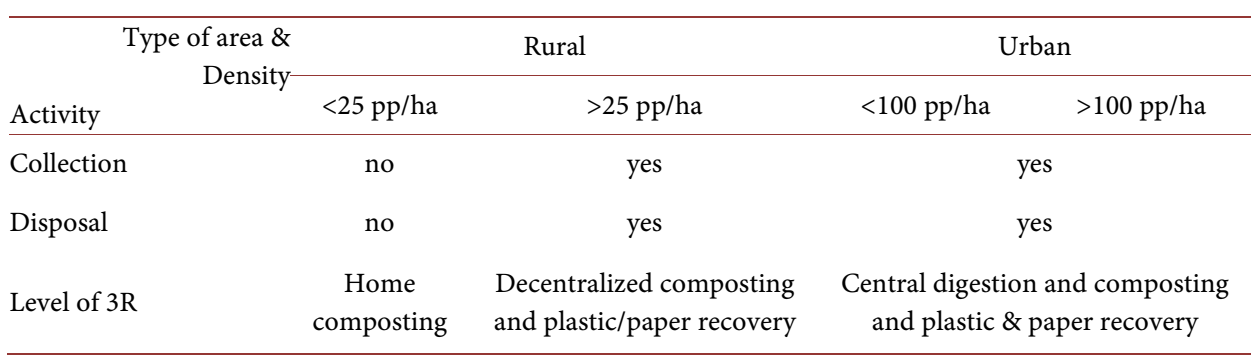

concentrations are calculated. The RIBASIM model and defined catchment areas are further explained in OSI Section 5. The pollution loads entering the Upper Citarum River were varied, using 6 scenarios (Table 5).

The output of the 2010 RISBASIM average pollutant concentrations was calibrated based on the average measured concentration (step 1).

\subsection{Step 5: Benefits Analysis of Different Interventions}

Five economic benefits of wastewater and solid waste management improvements were defined following [32] and [53]:

A. Health:

Averted costs of fecal-oral disease from improved on-site sanitation and wastewater management. An average disease reduction of $36 \%$ by on-site sanitation and an additional $20 \%$ by adding improved off-site facilities was applied [54]-[56]. The average annual health cost per 5 member family as a result of unimproved sanitation was US \$316 [31].

Associated averted health impacts (infectious diseases and skin complaints) of less exposure during flooding events: Reported health cases during a period of several flooding events (January-March 2009) were compared to the same period in a non-flood year (January to March 2010) and was scaled to reflect all the flooded communities in the Citarum River basin, resulting in an estimated 15,000 averted cases of diarrhea in an average year [53]. The economic value was estimated by multiplying the average number of additional cases per year by the unit cost of inpatient (hospitalized) and outpatient services, including productivity losses [31].

B. Access time:

Value of time savings from reduced travel time and/or queuing for meeting sanitation needs. An average daily gain of 115 minutes per household with an annual value of US $\$ 95$ per household is used [31]. Only the time of adults and school-aged children were included, valued at $30 \%$ and $15 \%$ of the hourly rate implied by the GDP per capita, respectively [57]. This figure was applied to the access gain afforded by on-site sanitation facilities of $45 \%$ of households for the period from 2010 until 2030.

C. Water:

Reduced drinking water treatment costs to households and industries. The total cost of water treatment (including both capital and operating costs) using surface water of a better quality source will decrease from 0.13 to $0.06 \mathrm{US} \$ / \mathrm{m}^{3}$ [16]. This saving was 
Table 5. Defined intervention scenario (S1 - S6); ST = Simple Technology ; AT = Advanced Technology and percentage of population served by a municipal solid waste (MSW) system.

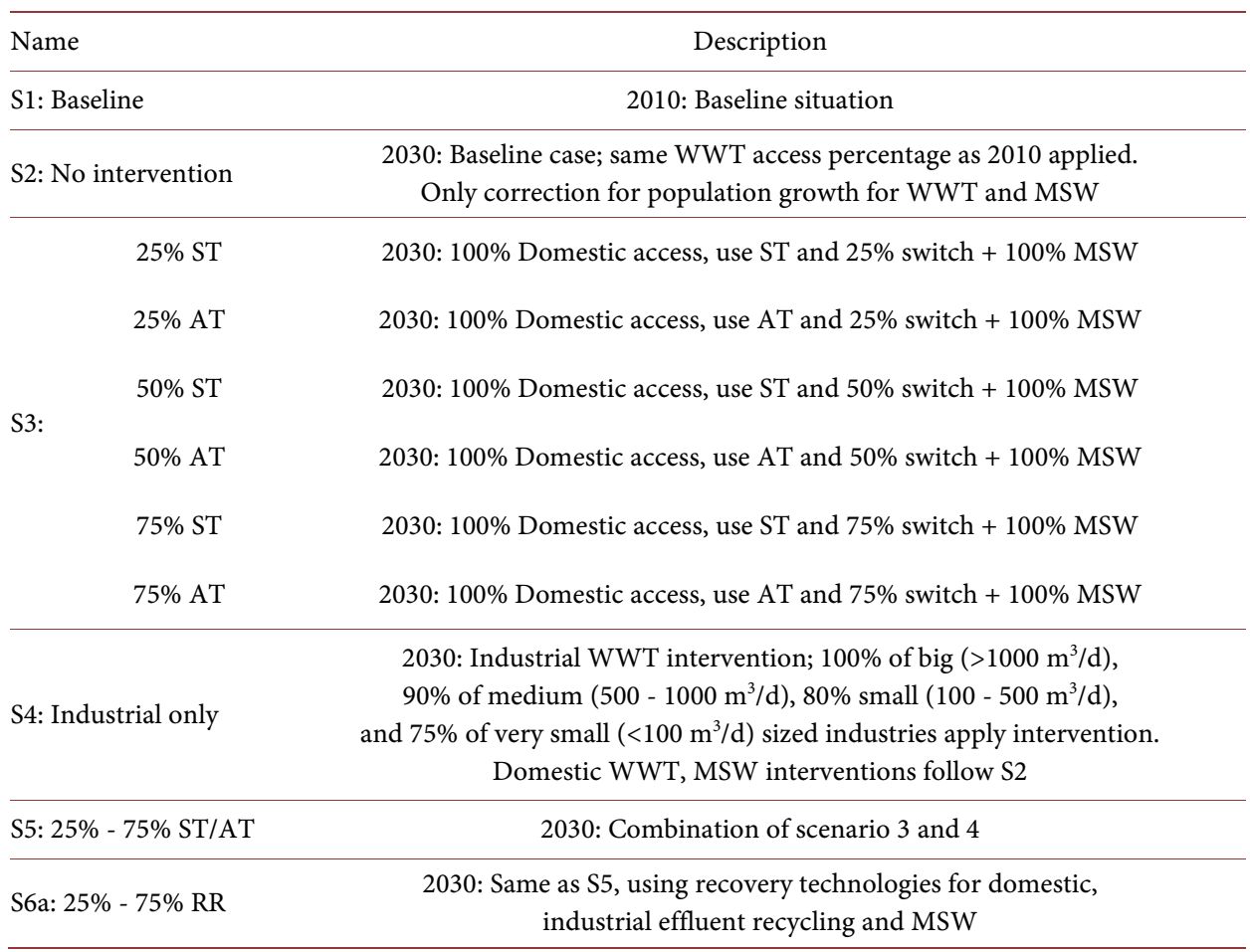

a: Except for S6, where a MSW resource recovery based system is applied, all other cases apply a conventional MSW system (no resource recovery).

multiplied by the assessed annual production of water from surface water sources (207 million $\mathrm{m}^{3}$ for domestic and 70 million $\mathrm{m}^{3}$ for industrial consumers) in 2030 .

Improved fish yields from farming in downstream lakes due to improved water quality: Data collected through interviews with the regional Fisheries Office showed a decrease in fish catch of 5,000 ton/year in recent years [58]. Fish kills in Saguling (Figure 1) related to discharge of untreated wastewater have been described by [12] and [23]. By 2030 the fish capture is estimated to increase by 8,000 metric tons per year [58]. The increase of improved water quality was assumed to account for one-third of this expected annual gain of farmed fish in the Citarum basin [53]. A market prices of fish of 1.5 US $\$ / \mathrm{kg}$ was used [58].

D. Environment:

Reduced frequency of river and reservoir dredging due to improved sludge and waste management. An estimated 35 1/person/year of septic waste [9] and $11 \%$ and $17 \%$ of domestic urban and rural solid waste [59] accumulating to nearly 500 ktonne/year are currently discharged to the surface water and will be prevented from being disposed in the surface water in 2030 with the described interventions (Table 5). With a cost of dredging estimated at US $\$ 3.76$ [16] per ton of sediment (assuming no degradation), the total annual cost averted was estimated.

Rise in land prices due to improved aesthetics of riverside and lakeside real estate: Currently the Citarum riverside area is not developed due to water pollution. However, 
the area is expected to become a place where riverside property could be developed for inhabitants, small businesses, and tourist facilities in a situation where water quality is improved. The current agricultural land price $\left(10.7 \mathrm{US} \$ / \mathrm{m}^{2}\right)$ in the vicinity of Bandung was used as a benchmark for current riverside land prices. The current market suggests that land prices can climb to $71.3 \mathrm{US} \$ / \mathrm{m}^{2}$ in highly desirable locations [16]. In this study $50 \%$ of this increase is attributed to improved water quality. This value was multiplied by an estimated 50 ha of land that could be developed each year after the water quality improvements have occurred [53].

Averted maintenance costs of hydro-electric facilities: Improved solid waste management would avert the current costs of US $\$ 0.1$ million [16] to evacuate the solid and unmanaged sludge waste to avoid equipment damage in the hydroelectric facility [53].

E. Recovery of resources:

In scenario 6, resource recovery was considered (see also Table S4 in the OSI, Section 4):

- Off-site wastewater systems: Production of energy (sludge digestion), struvite (from centrate) and compost (digested sludge composting).

- MSW: Energy and compost production from organic waste and recovery of plastics and paper.

- Industrial wastewater: industries with a water consumption exceeding $2000 \mathrm{~m}^{3} / \mathrm{d}$ reused $80 \%$ of the effluent, whereas for industries using $1000-2000 \mathrm{~m}^{3} / \mathrm{d}$ this was $50 \%$.

To compare the production (recovery) of resources with the potential demand in the Upper Citarum River catchment area in 2030, the compost, struvite, plastic and paper demand in the whole of West Java obtained from [29] was corrected for people living in the Upper Citarum River basin area. The amount of recycled water from industries was compared to the total domestic and industrial water demand in 2030 in the catchment area [16]. Energy production from digestion is compared to the energy demand for domestic wastewater treatment in the area applying aerobic granular sludge technology [19].

\subsection{Step 6: Assessment of Benefits versus Costs}

To relate benefits and costs to either wastewater or solid waste interventions, BCR's were presented separately. To analyze the individual impact of domestic, industrial and resource recovery interventions the BCR of scenarios S3: (50\% ST and S3: 50\% AT), S4: (Industrial interventions only), S5: (50\% ST; S5: 50\% AT) and S6 (50\% RR) were determined (see also Table 5). A sensitivity analysis was performed in which input values that have the highest anticipated impact were varied: (1) health and access time benefits reduced from $100 \%$ to $50 \%$, (2) lifespan of all wastewater and solid waste facilities varied from 20 years to 15 and 40 years, and (3) resource selling price reduced to half baseline values [32] [53]. Health and access time benefits were all attributed to domestic intervention. Water quality and environmental benefits were attributed to the fraction of COD load discharged by domestic and industrial sources respectively. 


\section{Results}

\subsection{Water Quality in Upper Citarum River}

Figure 3 shows the average 2000-2009 water quality from upstream to downstream locations. Maximum allowable concentrations are defined in class II standard [60] and are COD $25 \mathrm{mg} / \mathrm{l}$, BOD $3 \mathrm{mg} / \mathrm{l}$ and P $0.2 \mathrm{mg} / \mathrm{l}$. From Sapan on (Figure 1) all measured values exceed these standards. Concentrations in several Citarum branches passing high density urban areas, show COD values approaching $500 \mathrm{mg} / \mathrm{l}$ and pathogen levels as high as $10^{7}$ Units/100 $\mathrm{ml}[40]$.

\subsection{Sources of Pollution}

Current cumulative pollution loads in the Upper Citarum River basin of COD (585 tonne/d), BOD (264 tonne/d), TN (91 tonne/d) and TP (20 tonne/d) were determined as the baseline values (Table 6). The sensitivity analysis with variations in domestic pollution coefficient [18] and performance of industries shows considerable differences with the baseline scenario (Table 6) with COD loads varying between 325 and 688 tonne/d (see also OSI, Section 7).

\subsection{Effect of Selected Interventions on Costs and Pollution Loads}

The domestic pollution loads entering the Upper Citarum River depend on (1) the type of technology applied (simple versus advanced) and (2) the rate of current households applying on-site systems in urban areas that will switch to an off-site system (Figure 4). The use of advanced compared to simple technologies has a minor impact on COD removal in the range of $3 \%-4 \%$, but a major impact on $\mathrm{N}$-removal in which a rate of

Table 6. COD, BOD, TN and TP pollution loads reaching the surface water by source for the baseline scenario and varying pollution correction factors and industrial practices.

\begin{tabular}{l|c|c|c|c|c}
\hline \multirow{2}{*}{ Source } & Scenario & $\begin{array}{c}\text { COD } \\
\text { (tonne/d) }\end{array}$ & $\begin{array}{c}\text { BOD } \\
\text { (tonne/d) }\end{array}$ & $\begin{array}{c}\text { TN } \\
\text { (tonne/d) }\end{array}$ & $\begin{array}{c}\text { TP } \\
\text { (tonne/d) }\end{array}$ \\
\hline \multirow{3}{*}{ Domestic } & Baseline loads & 388 & 188 & 68 & 12 \\
\cline { 2 - 6 } & Half of baseline loads reach surface water & 194 & 94 & 34 & 6 \\
\hline \multirow{3}{*}{ Industrial } & Baseline & 163 & 60 & 6 & 2.6 \\
\cline { 2 - 6 } & Best case & 98 & 33 & 4 & 2.2 \\
\hline \multirow{2}{*}{ Agriculture } & Worst case & 215 & 80 & 8 & 3.0 \\
\hline \multirow{3}{*}{ Total } & Baseline ${ }^{\mathrm{a}}(\mathrm{S} 1)$ & 34 & 17 & 16 & 5 \\
\cline { 2 - 6 } & Minimum $^{\mathrm{b}}$ & 585 & 264 & 91 & 20 \\
\cline { 2 - 6 } & Maximum $^{\mathrm{c}}$ & 325 & 144 & 54 & 13 \\
\hline
\end{tabular}

a. Total baseline values comprise domestic and industrial baseline loads + agricultural loads; b. Total minimum values add domestic low pollution correction coefficient and Industrial best case + agricultural loads; $c$. Total maximum values add domestic high pollution correction coefficient and Industrial worst case + agricultural loads. 


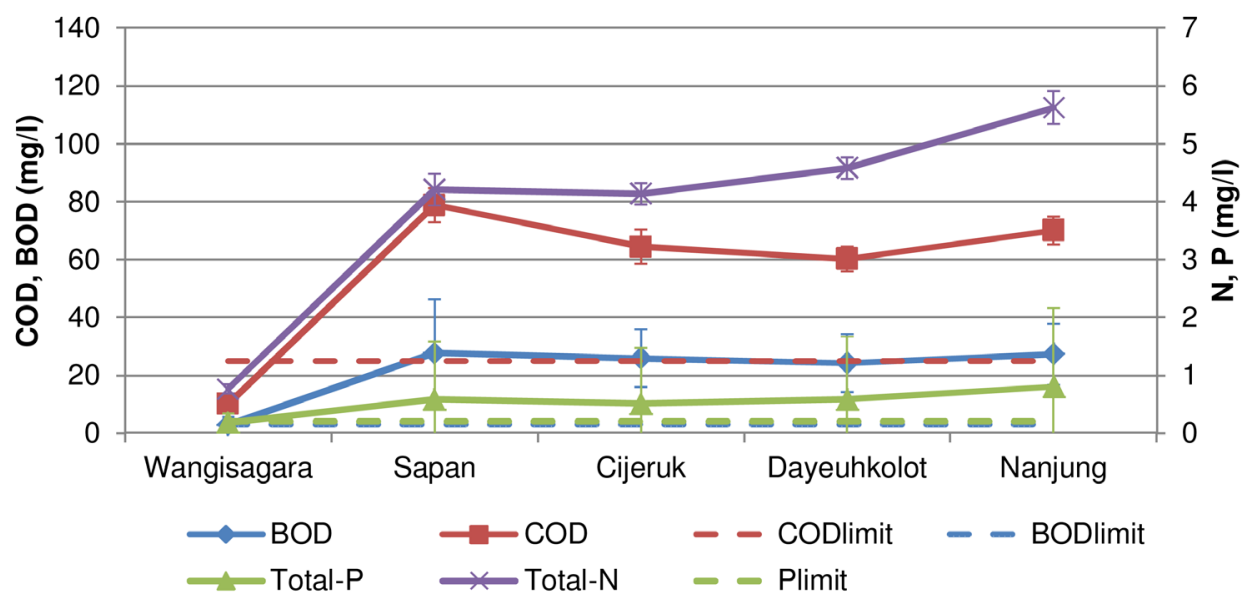

Figure 3. Average and standard variations of COD, BOD (primary y-axis) and $\mathrm{N}, \mathrm{P}$ (secondary $y$-axis) concentrations at indicated locations in the upper Citarum (2000-2009) [39] and COD, BOD and $\mathrm{N}$ limits.
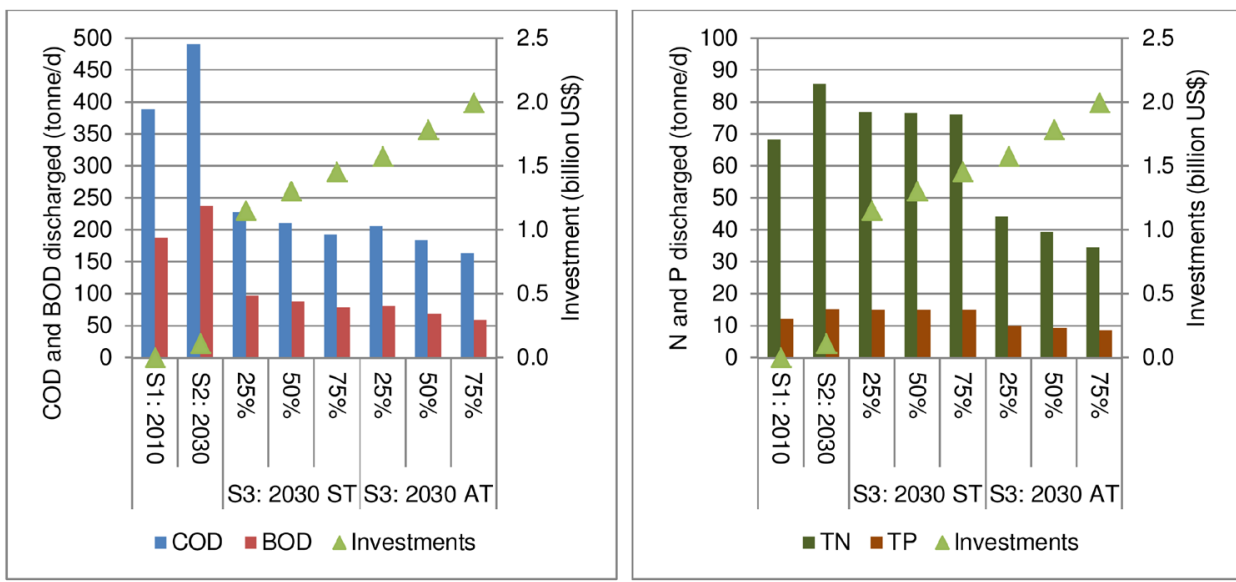

Figure 4. Calculated domestic COD, BOD (left) and N, P (right) pollution loads per type of intervention and their investment costs (secondary y-axis). S1 (baseline), S2 (no intervention) and S3 (domestic interventions) applying simple (ST) or advanced technologies (AT) with increasing $(25 \%, 50 \%$ and $75 \%)$ values for urban on-site users that switch to off-site systems.

$25 \%$ households switching to off-site systems leads to a $29 \%$ difference and a rate of $75 \%$ households switching to off-site systems leads to a $37 \%$ difference (Figure 4 ).

When increasing the switch factor from $25 \%$ to $75 \%$, the additional removed COD and $\mathrm{N}$ increased with $5 \%$ and $1 \%$ for simple technologies and $6 \%$ and $9 \%$ for advanced technologies. BOD removal follows the COD trend, whereas $\mathrm{P}$ removal follows the $\mathrm{N}$ trend. Thus, the application of advanced technologies or a higher rate of people switching from on-site system to off-site systems mainly affects the additional nutrient removal, while organic removal is less affected. The numeric values of this analysis and further elaboration on costs of interventions and their impact on water quality are described in the OSI, Section 7.

The industrial pollution load amounts to $28 \%$ of the total load (Table 6 ), but indus- 
trial interventions can result in a relatively large COD reduction (35\%) compared to the combined domestic and industrial COD reduction (see also OSI, Section 7).

\subsection{Effect of Interventions on Water Quality}

Figures 5(a)-(f) shows the effect of interventions on the year round average water quality at different locations. The location names are approximate locations, as RIBASIM calculates concentrations in defined segments of a river (see OSI, Figure S8). Without

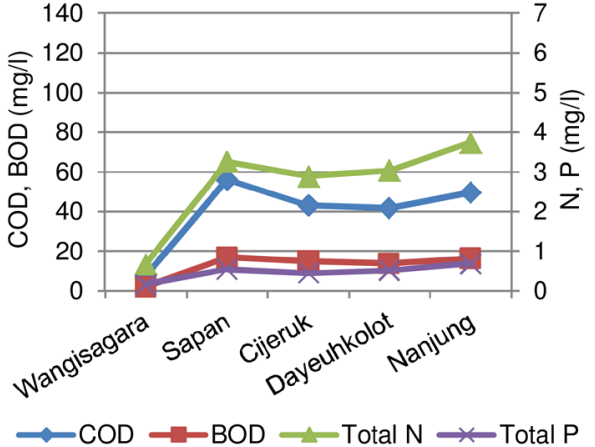

(a)

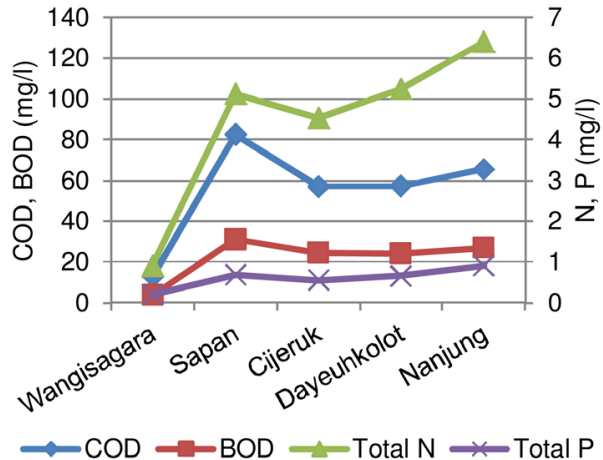

(c)

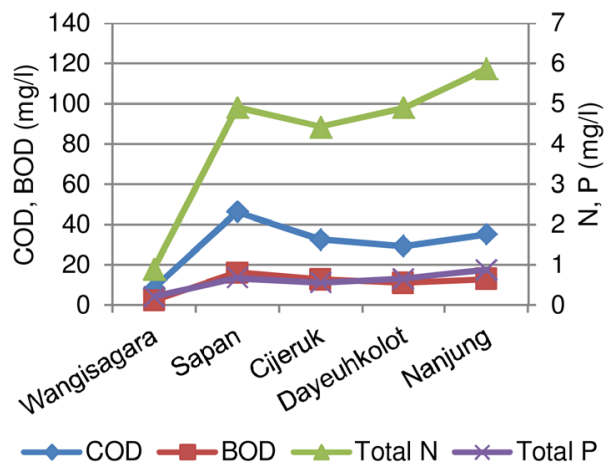

(e)

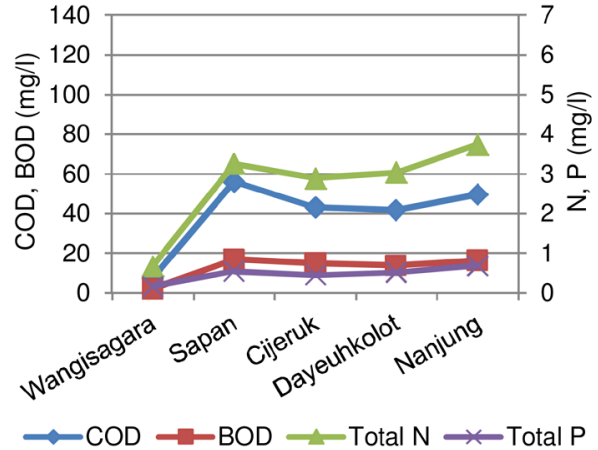

(b)

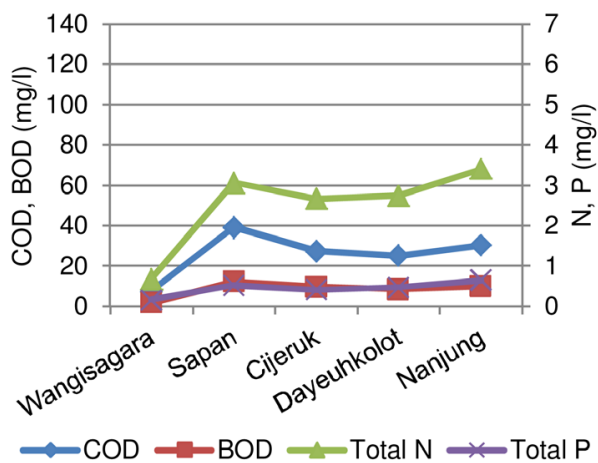

(d)

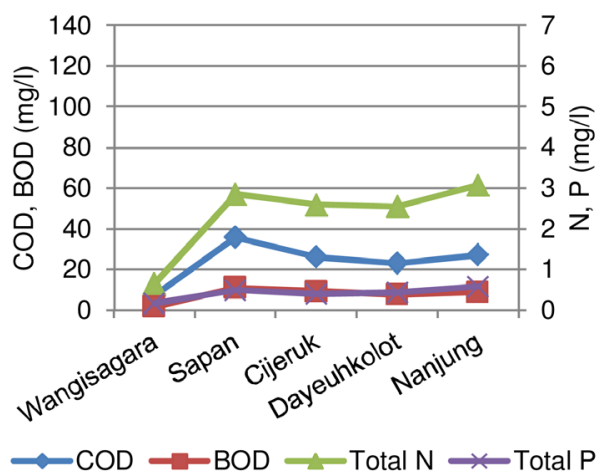

(f)

Figure 5. Modelled COD, BOD (primary y-axis) and N, P (secondary y-axis) concentrations at indicated locations in 2030 with varying switch factors \% and simple (ST) or advanced technologies AT). (a) S2, no intervention; (b) S3: 50\% AT); (c) S4: Industrial only; (d) S5: 50\% AT; (e) S6: 25\% ST; (f) S6: 75\% AT. Limits for COD, BOD, and P are $100 \mathrm{mg} / \mathrm{l}, 3 \mathrm{mg} / \mathrm{l}$ and $0.2 \mathrm{mg} / \mathrm{l}$. 
additional interventions all concentrations will increase compared to the 2010 values (Figure 3) with values as high as $100 \mathrm{mg} / \mathrm{l}$ of COD (Figure 5(a)). The modeled pollutant concentrations in water entering Saguling reservoir (approximate location Nanjung) are $80 \mathrm{mg} / \mathrm{l} \mathrm{COD}$, and $7 \mathrm{mg} / \mathrm{l} \mathrm{TN}$ and $1 \mathrm{mg} / \mathrm{l} \mathrm{TP}$. When applying S3 with 50\% AT (Figure 5(b)) a considerable drop in all pollution concentrations is achieved, whereas the introduction of industrial interventions result in approximately $20 \%$ COD \& BOD removal and about $4 \% \mathrm{~N} \& \mathrm{P}$ removal (Figure 5(c)). The combination of these interventions (S5: 50\% AT; Figure 5(d)) results in concentrations of $30 \mathrm{mg} / \mathrm{l}$ for COD, 10 $\mathrm{mg} / \mathrm{l}$ for BOD, $3.4 \mathrm{mg} / \mathrm{l}$ for $\mathrm{TN}$ and $0.7 \mathrm{mg} / \mathrm{l}$ for $\mathrm{TP}$. The maximum removal scenario (Figure 5(f)) results in values approximating the class II standard (COD $<25, \mathrm{BOD}<$ 3, $\mathrm{P}<0.2 \mathrm{mg} / \mathrm{l}$ ). Comparing Figure 5(e) (ST) with Figure 5(f) (AT) shows limited impact on COD or BOD removal, while considerable extra $\mathrm{N}, \mathrm{P}$ removal is shown when using advanced instead of simple domestic technologies.

To reach the desired water quality levels (class II) both industrial and domestic municipal interventions are needed. In addition, the applied off-site technologies should also include $\mathrm{N}$ and $\mathrm{P}$ removal, requiring more advanced and more costly technologies (see Figure 4) compared to the application of only anaerobic filters.

\subsection{Benefits of Interventions}

The maximum quantified economic benefits are US $\$ 430$ million per year in which health benefits account for $39 \%$ (Figure 6). Health benefits largely result from reductions in fecal-oral diseases, since 1) the people without access to wastewater (on-site and Bojong Soang WWTP) facilities (48\%) all have access by 2030 (55.2\% of health benefits), and 2) people that have access to a well-managed off-site or fecal sludge management system increased from $7 \%$ to $73 \%$ ( $44.6 \%$ of health benefits). Associated averted health impact due to irregular flooding events is only US $\$ 0.3$ million.

Convenience and time savings are among the top five reasons for having a latrine in the home area [31]. Based on [31] a mean annual gain of US \$77 million was determined for an additional $45 \%$ of the population in 2030 having access to their own

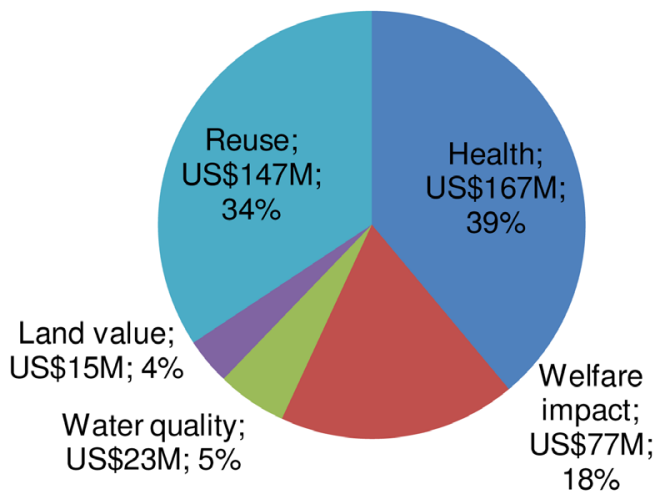

- Health

- Welfare impact

Water quality

- Land value

Reuse

Figure 6. Contribution of calculated overall economic benefits expressed in million US \$ (total US $\$ 430$ million) of each monetized impact (Scenario 6). Sedimentation (US \$2M; $0 \%$ contribution) and Dam maintenance (US $\$ 0.1 ; 0 \%$ contribution) are not shown. 
latrine facilities. This estimate is conservative as 1) it excludes travel needs for urination purposes, and 2) time is valued conservatively at $30 \%$ of the GDP per capita at hourly values.

US $\$ 13.9$ million of the total US $\$ 23$ million reduction in water treatment cost will accrue to the public water utilities and their consumers, while industries are expected to benefit US $\$ 4.7$ million annually. The value of farmed fish yields is expected to be US $\$ 4$ million annually.

The combined environmental benefits (increased land value, reduced dredging, averted maintenance costs of hydro-electric facilities) amount to US $\$ 17$ million, of which nearly $90 \%$ is attributed to increases in land value based on annual land sales. The benefits of reduced dredging (even assuming no decomposition or organic waste) have minor benefits.

Table 7 shows the estimated reuse benefits based on the per capita production features and resource values (Table S4 in OSI). 87\% of the US $\$ 147$ million yearly potential revenues are from municipal solid waste, $11 \%$ from domestic wastewater treatment and recovery and reuse of its resources and recycling, and $2 \%$ from industrial wastewater treatment and recycling. The potential demand for recoverable resources is higher than the potential supply through recovery (Table 7), ranging from a factor 13 for water to a factor 1.6 for plastic.

\subsection{Assessment of Benefits versus Costs}

Following the anticipated benefits (Figure 6) and corresponding investment and operational costs (Table S6 in OSI, Section 8) the BCR was calculated (Figure 7). The BCR varied between the interventions. The highest BCR of 3.2 is achieved by implementing simple technologies (S3: $50 \% \mathrm{ST}$ ), in other words an economic return of US $\$ 3.2$ is anticipated for each US $\$ 1$ invested. Because of higher costs for AT compared to ST, the $\mathrm{BCR}$ is expected to be lower for the AT scenario (BCR in S3: 50\% AT = 2.06). The lowest BCR (0.52) is found in scenario 4 (industrial interventions alone). A joint approach

Table 7. Resource recovery potential, sector of recovery (Domestic, Industrial or MSW), potential demand, recovery percentage and annual economic values associated with reuse options based on baseline prices (Table S4 in OSI).

\begin{tabular}{lcccccccc}
\hline & \multicolumn{5}{c}{ Recoverable resources per sector and potential demand } & Total \\
\cline { 2 - 7 } Parameter & $\begin{array}{c}\text { Domestic } \\
\text { WWT }\end{array}$ & $\begin{array}{c}\text { Industrial } \\
\text { WWT }\end{array}$ & MSW & $\begin{array}{c}\text { Total } \\
\text { recovery }\end{array}$ & $\begin{array}{c}\text { Potential } \\
\text { demand }\end{array}$ & Unit & $\begin{array}{c}\text { Recovery } \\
\text { percentage }\end{array}$ & $\begin{array}{c}\text { revenues } \\
\text { (million US } \\
\$ / \text { year) }\end{array}$ \\
\hline Compost & 91 & - & 351 & 442 & 1240 & ktonne/y & $36 \%$ & 44.2 \\
Plastic & - & - & 228 & 228 & 366 & ktonne/y & $62 \%$ & 45.5 \\
Paper & - & - & 193 & 193 & 1185 & ktonne/y & $16 \%$ & 38.6 \\
Electricity & 27 & - & 89 & 116 & 78.8 & GWh/y & $147 \%$ & 11.6 \\
Water & - & 43 & - & 43 & 563 & Mm $3 / y$ & $8 \%$ & 2.6 \\
Struvite & 4.2 & - & - & 4.2 & 35 & $\mathrm{ktonne} / \mathrm{y}$ & $12 \%$ & 4.1 \\
Total economic value & & & & & & & 146.6 \\
\hline
\end{tabular}




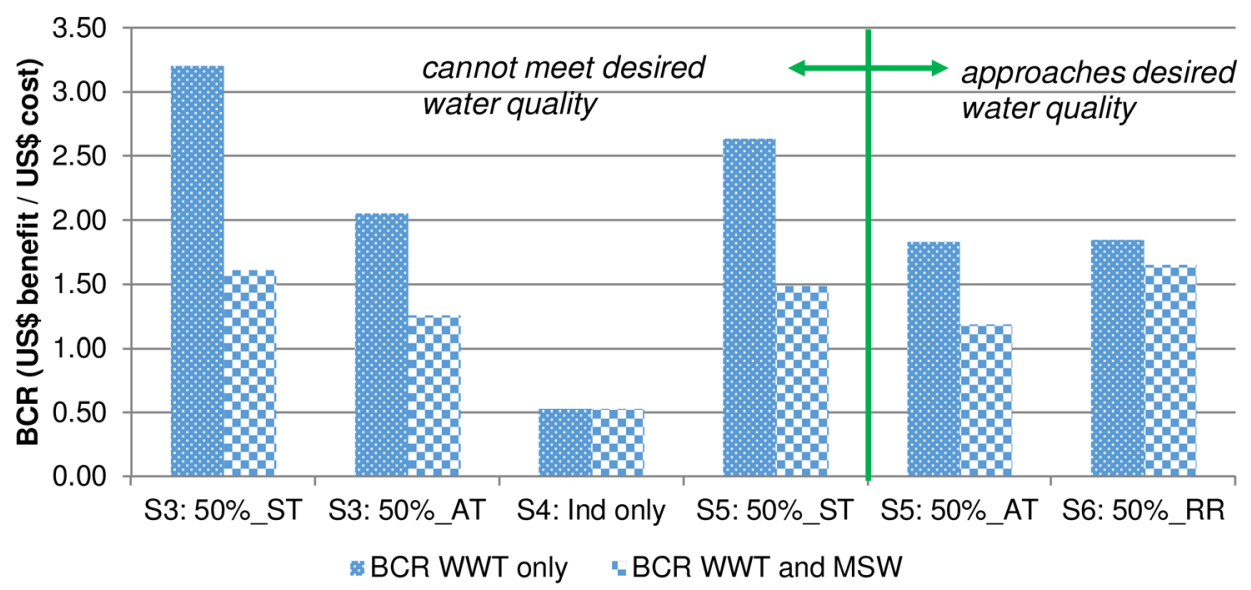

Figure 7. Calculated BCR per analyzed scenarios, differentiating the BCR in which only wastewater treatment (WWT) interventions are considered and the BCR that considers both WWT and municipal solid waste (MSW) interventions. Scenarios that approach the target water quality are S5: 50\%-AT and S6: 50\%-RR.

tackling both domestic and industrial pollution results in a BCR ranging from 1.83 (S5: $50 \%$ AT) to 2.64 (S5: 50\% ST). However, simple technologies were not found sufficient to improve the water quality to levels approaching class II, especially in terms of nutrient (N, P) removal (Figure 5).

The economic returns on combined wastewater and solid waste interventions are lower than the returns on wastewater interventions only (Figure 7). Economic costs related to absence of solid waste services are associated with unhygienic living conditions [31], loss of tourism developments or value of land [61]. Loss of land value, however, contributes to only a fraction (4\%) of total related economic impact (Figure 6) and on their own do not outweigh the estimated costs (see Table S6 in OSI) to establish the MSW management systems. The willingness of households to pay for solid waste collection and treatment services has been better established compared to wastewater services in Indonesia [62]. This may be attributed to direct visibility of improving solid waste management [63]. Consequently, there is a larger potential for recovering some of the costs through MSW tariffs paid by households compared with tariffs for wastewater services. Potential revenues from fees were excluded from the BCR analysis, but are relevant for development of a cost-effective wastewater and solid waste management system.

Additional benefits of resource recovery from MSW can be a driver for improving water quality. The BCR (including MSW) of scenario 5 (applying AT) is 1.19 and will increase to 1.65 by applying resource recovery (Table 8). The BCR of scenario 6 with MSW recovery is even higher than the BCR of Scenario 5 applying ST (1.49) showing that required additional costs to improve the water quality can be financed through the sale of resources recovered from solid waste. However, application of resource recovery from wastewater only results in a minor increase in BCR (from 1.83 to 1.85) compared to applying only advanced technology. Thus, from a financial perspective using existing market prices, the additional investments to recover resources from wastewater out 
Table 8. Calculated Benefits Costs Ratio (BCR) and five alternative BCR's distinguishing (A) only WWT based BCR or (B) WWT and MSW based BCR.

\begin{tabular}{|c|c|c|c|c|c|c|c|c|c|c|c|c|c|}
\hline \multirow[b]{2}{*}{ 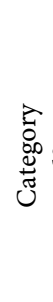 } & \multirow[b]{2}{*}{ Sub category } & \multicolumn{6}{|c|}{ A. WWT costs and benefits } & \multicolumn{6}{|c|}{ B. WWT and MSW costs and benefits } \\
\hline & & $\begin{array}{l}\tilde{n}^{1} \\
\hat{0}^{\prime} \\
\ddot{n}\end{array}$ & $\begin{array}{l}e_{1} \\
\text { Oे } \\
\text { in } \\
\ddot{\ddot{n}}\end{array}$ & 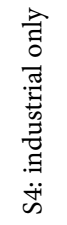 & $\begin{array}{l}\omega_{n} \\
\delta^{\prime} \\
i \\
\ddot{n}\end{array}$ & 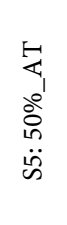 & 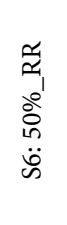 & $\begin{array}{l}\dot{n}_{1} \\
\dot{0} \\
\dot{0} \\
\ddot{n}\end{array}$ & 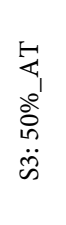 & 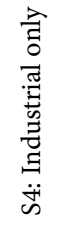 & $\begin{array}{l}\omega_{1} \\
\partial^{\prime} \\
\dot{0} \\
\ddot{n}\end{array}$ & $\begin{array}{l}H_{1} \\
\text { 官 } \\
\ddot{n} \\
\ddot{n}\end{array}$ & 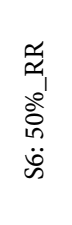 \\
\hline \multirow{6}{*}{ 孞 } & Baseline BCR & 3.20 & 2.06 & 0.52 & 2.64 & 1.83 & 1.85 & 1.62 & 1.26 & 0.52 & 1.49 & 1.19 & 1.65 \\
\hline & $\begin{array}{l}\text { Resource prices } 50 \% \text { of } \\
\text { baseline }\end{array}$ & 3.20 & 2.06 & 0.52 & 2.64 & 1.83 & 1.79 & 1.62 & 1.26 & 0.52 & 1.49 & 1.19 & 1.37 \\
\hline & $\begin{array}{l}\text { Health impact } 50 \% \text { of } \\
\text { baseline }\end{array}$ & 2.22 & 1.42 & 0.52 & 1.86 & 1.29 & 1.34 & 1.12 & 0.87 & 0.52 & 1.05 & 0.84 & 1.33 \\
\hline & 40 year capital lifespan & 4.94 & 3.01 & 0.60 & 3.80 & 2.58 & 2.61 & 2.11 & 1.65 & 0.60 & 1.91 & 1.54 & 2.18 \\
\hline & 15 year capital lifespan & 2.60 & 1.70 & 0.48 & 2.19 & 1.53 & 1.55 & 1.40 & 1.09 & 0.48 & 1.29 & 1.03 & 1.42 \\
\hline & $\begin{array}{l}\text { Access time gained } 50 \% \text { of } \\
\text { baseline }\end{array}$ & 2.75 & 1.76 & 0.52 & 2.28 & 1.58 & 1.61 & 1.39 & 1.08 & 0.52 & 1.28 & 1.03 & 1.50 \\
\hline
\end{tabular}

weigh the benefits by a small margin.

In case recovered resources are sold at only half the current market price (Table 8) the BCR of resource recovery (S6) is lower than for AT, but still higher than 1 . The BCR may change depending on the lifespan of capital stock (Table 8). A lifespan of 40 years results in a BCR approaching 5 (S3: 50\%_ST). A major part of the cost (Table S1 in OSI) is related to sewer system developments that have typically much longer potential lifespans (even up to 100 years) [64] and therefore it is likely the BCR will be higher than the baseline BCR of 3.2 for that same scenario (S3: 50\%_ST).

\section{Discussion}

\subsection{Added Value of Integrated Approaches}

Evaluating the economic performance of wastewater and solid waste interventions is a complex process, involving many variables and alternative combinations and coverage levels of interventions. Therefore a methodology was developed that combines several assessment methods and data sources in order to support decision making. The added value of the integrated approach allows for a nuanced view on interrelations compared to single cause-effect relations [65]. Thus the effects of different interventions on water quality, resource recovery potential, and related economic returns could be evaluated in parallel (Figures 5-7). This parallel evaluation provides significant benefits in a dynamic context [66]. It also addresses the need for a method that can quantitatively evaluate a set of sanitation alternatives to resolve trade-offs across sustainability dimensions (social, environmental, and economic) [67].

\subsection{Added Value of the Approach in Practical Applications}

The practical application of the integrated approach is first demonstrated in the analy- 
sis of contribution of pollution per sector (industry, domestic or agriculture) related to the pollution prevention costs. The large contribution of domestic pollution was unambiguous and confirmed in a sensitivity analysis (see also OSI, Section 7). Presented results are in line with findings of [13] who determined that households contributed 55\%, industries $40 \%$ and agriculture $6 \%$ of BOD pollution entering the Saguling reservoir. Reference [11] demonstrated the importance of fertilizer use management to avoid future coastal eutrophication in Indonesian Rivers, which corresponds with the large nutrient load as a result of agricultural activities (25\% for P) determined in the current study. Despite a relative low (28\%) contribution of industrial COD pollution, 35\% of COD can be reduced by industrial interventions, whereas the investment costs for industrial interventions are less than $10 \%$ of the domestic interventions (Table S6 in OSI). Further, the number of industries is only a fraction $(\sim 1 \%)$ of the number of households in the Citarum area and monitoring interventions would be much more practical than monitoring individual household connections. Thus, although COD pollution from industry is relatively small, it is more cost effective (>factor 5 ) than domestic, which may help a policy maker in prioritizing interventions.

Secondly, the integrated approach supports determination of cost-effective interventions. The added value of applying more advanced technologies or switching more people to a sewer system showed that required additional investments can be justified from the point of nutrient removal, but less so from COD removal (Figure 4). In addition, the use of software tools like RIBASIM to model and estimate the impact of discharged pollution loads on the anticipated water quality allows the policy maker to relate interventions and their cost to applicable water quality standards.

Thirdly, linking the resource recovery potential and its revenues to its potential demand may benefit formulation of policies or increase government involvement to foster financial sustainability of sanitation facilities [24]. The value of recoverable resources from solid waste has resulted in a very active, but informal waste recovery sector in Indonesia [68] [69]. In addition, the demonstrated potential recovery of resources exceeding the agricultural demand allows for selective marketing, focusing on safe reuse (e.g. on non-edible crops) [70] [71]. Electricity production from the joint wastewater and solid waste facilities is potentially higher than the demand for domestic wastewater and supports the potential for a joint development of wastewater and solid waste facilities [72].

Fourthly, monetizing both direct use and indirect non-use values of sanitation implementation in relation to achievable surface water quality enables the formulation of a cost and environmental effective approach. The performed analysis demonstrated that the most cost effective scenario (S3: 50\%_ST) with the highest BCR differs from the scenario reaching the required water quality (e.g. S5: 50\%_AT). Therefore, a policy maker needs to prioritize between these two options. As a cost effective strategy, application of advanced technologies may be restricted to the most highly densely populated urban areas (where most pollution is produced). Alternatively, a phased approach in which first simple (low cost) technologies are implemented that are later replaced, con- 
verted or extended by systems that allow for nutrient removal [73]. Monetizing benefits may further help to raise funds from other sources or actors that benefit from improved water quality, such as residential project developers or tourism sites [32].

The outcomes of the study were formulated in a planning document for the Indonesian government [53] and confirmed our hypothesis that quantification of tangible outputs using the presented approach can support policy-makers in the field.

\subsection{Options for Extending the Approach}

The presented framework can be further extended given the following considerations:

- To assess the sustainability of interventions and ensure that pollution is being removed and not displaced, environmental emissions other than water pollution (COD, $\mathrm{N}, \mathrm{P}$ ), such as odor or greenhouse gasses may be included. The effect of greenhouse gasses emitted by low cost technologies (e.g. anaerobic filters or septic tanks) is excluded from the current evaluation.

- In the determination of the water quality, several assumptions were made that may affect obtained results and could be incorporated in a next phase (see also OSI Section 9). First, a connection between surface and ground water was assumed in which infiltrated septic tank effluent load directly influences the surface water quality. Second, RIBASIM model disregards biological conversion of pollutants in the surface water, whereas these are observed in the field [12]. Third, all interventions are assumed to be designed, constructed, operated and maintained correctly, which may be optimistic in view of current practice [37] [74]. Fourth, the effect of dumped solid waste on water quality is excluded. Finally, surface water pollution from animal manure was excluded.

- The low BCR of industrial interventions (0.52, Table 8) and the weak mandatory industrial regulation in Indonesia [75] may suggest limited possibilities to implement industrial pollution prevention. However, alternative means to spur Indonesian industries to comply with environmental standards such as public disclosure (the regular collection and dissemination of information about firms' environmental performance) have been shown to be effective [76].

- Aerobic technologies were used as industrial references, whereas the use of anaerobic technologies may result in lower investment and/or operational costs [77] [78].

- Not all economic impacts were quantified in this study (see also OSI, Section 10), such as consumption of fish imbibing toxic wastes or otherwise infected [79], reduced land subsidence and improved recreational values [30] [80]. In addition, long-term impacts on the river and population of industrially discharged toxins and heavy metals were excluded and would specifically increase the BCR of scenario S4 (industrial intervention). Although the current study focuses on a part of a river basin only and uses locally collected data, a further detailing on a city or community level may be required to prevent overgeneralization and misunderstanding of individuals' preference tradeoffs [81]. 
- Applying advanced technologies (AT) will improve water quality (Figure 5), but will not increase quantified health or welfare impact. At the same, anticipated longterm effects of reduced eutrophication and less impacted ecosystem functioning [11] were not quantified, whereas these would further increase the BCR.

- The BCR considers the overall societal perspective, whereas different costs and benefits are incurred and enjoyed by different stakeholders. Thus, the costs of domestic interventions are to a large extent paid for by the national and local governments (in Indonesia $\sim 70 \%$ ) and to lesser extent by individual households [50], whereas industries typically pay the costs of the interventions themselves [37]. Benefits of improved water quality as a result of interventions can be either increased revenues (e.g. sale of recovered resources) or averted costs (e.g. lower water treatment costs) which benefit a single party, or are generalized to the population (e.g. averted health or time costs) which benefit society as a whole [30]. In the elaboration of a planning document, the incidence of costs and benefits should be further detailed. In addition, serious institutional challenges have been identified in providing access to sanitation in a development world's context [82]. To implement the planned sanitation development, the responsible institutions need to be identified and budgets should be allocated. A methodology to do this, involving private households, local and national governments, was described by [50].

\section{Conclusions}

In this study, an integrated method was presented that quantified the economic costs and benefits of wastewater and solid waste interventions in relation to water quality improvements and resource recovery potential. The approach provides added value in the decision making process in a complex and dynamic context since it helps resolve trade-offs across different dimensions of sustainability (e.g. social, environmental and economic).

Identification of pollution sources and the impact of interventions on discharged pollution loads allows for prioritizing of actions. By simultaneously modeling the water quality and cost impact of variations in 1) type of technology and 2) the household numbers switching from poor-performing septic tanks to off-site systems, insight into the cost-effectiveness of environmental policies is provided. This allows a policy maker to optimize economic and water quality benefits.

In the presented case of the Upper Citarum River, domestic interventions applying simple technologies were most attractive, with an estimated BCR of 3.2. However, to achieve the target water quality both industrial and advanced domestic WWT technologies would be required, leading to an estimated BCR of 2.0. Resource recovery from MSW was found to be a driver for improving water quality, as benefits through the sale of recovered resource outweighed the additional costs to improve the water quality.

\section{Acknowledgements}

The authors acknowledge the contribution of Aart van Nes, Fery Hardianto and Wil 
van der Krogt in the data collection and RIBASIM modeling as part of the 6 Ci's project funded by the ADB (TA7189-INO: Institutional Strengthening for Integrated Water Resources Management (IWRM) in the 6 Ci's River Basin Territory-Package B). The economic works of this study was funded by WSP's Multi-Donor Trust Fund for WSP East Asia and the Pacific, supported by the Government of Australia. Guy Hutton conducted the work while employed at the World Bank. We thank Isabel Blackett, Almud Weitz, Enrico Rahadi Djonoputro, and Deviariandy Setiawan for their valuable input. In loving memory of pak Nugroho-Director of Urban, Housings and Settlements, National Development Planning Agency (Bappenas); may you rest in peace.

\section{References}

[1] WHO and UNICEF (2015) Progress on Sanitation and Drinking Water-2015 Update and MDG Assessment. Geneva, Switzerland.

[2] Corcoran, E., Nellemann, C., Baker, E., Bos, R., Osborn, D. and Savelli, H. (2010) Sick Water? The Central Role of Wastewater Management in Sustainable Development. A Rapid Response Assessment. United Nations Environment Programme, UN-HABITAT, GRIDArendal.

[3] ADB (2013) Indonesia: Water Supply and Sanitation Sector Assessment, Strategy, and Road Map. Manilla, Philippines.

[4] ADB (2014) Urban Water Supply and Sanitation in Southeast Asia: A Guide to Good Practice. Manilla, Philippines.

[5] Shuval, H. (2003) Estimating the Global Burden of Thalassogenic Diseases: Human Infectious Diseases Caused by Wastewater Pollution of the Marine Environment. Journal of Water and Health, 1, 53-64.

[6] Montgomery, M.A.A. and Elimelech, M. (2007) Water and Sanitation in Developing Countries: Including Health in the Equation. Environmental Science \& Technology, 41, 17-24. http://dx.doi.org/10.1021/es072435t

[7] Waddington, H. and Snilstveit, B. (2009) Effectiveness and Sustainability of Water, Sanitation, and Hygiene Interventions in Combating Diarrhoea. Journal of Development Effectiveness, 1, 295-335. http://dx.doi.org/10.1080/19439340903141175

[8] Surinkul, N. and Koottatep, T. (2009) Advanced Sanitation Planning Tool with Health Risk Assessment: Case Study of a Peri-Urban Community in Thailand. Human and Ecological Risk Assessment, 15, 1064-1077. http://dx.doi.org/10.1080/10807030903153469

[9] WSP (2013) Assessment of Sludge Accumulation and Pit Filling Rates in Indonesia. Jakarta, Indonesia.

[10] Wright, J., Cronin, A., Okotto-Okotto, J., Yang, H., Pedley, S. and Gundry, S.W. (2013) A Spatial Analysis of Pit Latrine Density and Groundwater Source Contamination. Environmental Monitoring and Assessment, 185, 4261-4272. http://dx.doi.org/10.1007/s10661-012-2866-8

[11] Suwarno, D., Löhr, A., Kroeze, C. and Widianarko, B. (2013) Past and Future Trends in Nutrient Export by 19 Rivers to the Coastal Waters of Indonesia. Journal of Integrative Environmental Sciences, 10, 55-71. http://dx.doi.org/10.1080/1943815X.2013.772902

[12] Hart, B.T., van Dok, W. and Djuangsih, N. (2002) Nutrient Budget for Saguling Reservoir, West Java, Indonesia. Water Research, 36, 2152-2160. http://dx.doi.org/10.1016/S0043-1354(01)00428-6 
[13] Suharyanto and Matsushita, J. (2011) Integrated Basin-Based Wastewater Management System for Water Pollution Control in an Enclosed Waterbody of the Upper Citarum River Basin, Indonesia: Case study of Saguling Reservoir. Lakes \& Reservoirs. Research \& Management, 16, 185-193. http://dx.doi.org/10.1111/j.1440-1770.2011.00473.x

[14] Fulazzaky, M.A. (2010) Water Quality Evaluation System to Assess the Status and the Suitability of the Citarum River Water to Different Uses. Environmental Monitoring and Assessment, 168, 669-684. http://dx.doi.org/10.1007/s10661-009-1142-Z

[15] Ujang, Z. and Henze, M. (2006) Municipal Wastewater Management in Developing Countries: Principles and Engineering. IWA Publishing, Illustrate.

[16] MoPW (2011) TA7189-INO: Institutional Strengthening for Integrated Water Resources Management (IWRM) in the 6 Ci's River Basin Territory-Package B. Jakarta, Indonesia.

[17] Abu Ghunmi, L., Zeeman, G., Fayyad, M. and van Lier, J.B. (2011) Grey Water Treatment Systems: A Review. Critical Reviews in Environmental Science and Technology, 41, 657698. http://dx.doi.org/10.1080/10643380903048443

[18] Hatt, B.E., Fletcher, T.D., Walsh, C.J. and Taylor, S.L. (2004) The Influence of Urban Density and Drainage Infrastructure on the Concentrations and Loads of Pollutants in Small Streams. Environmental Management, 34, 112-124. http://dx.doi.org/10.1007/s00267-004-0221-8

[19] Kerstens, S.M., Leusbrock, I. and Zeeman, G. (2015) Feasibility Analysis of Wastewater and Solid Waste Systems for Application in Indonesia. Science of the Total Environment, 530531, 53-65. http://dx.doi.org/10.1016/j.scitotenv.2015.05.077

[20] Antonopoulos, I.-S., Perkoulidis, G., Logothetis, D. and Karkanias, C. (2014) Ranking Municipal Solid Waste Treatment Alternatives Considering Sustainability Criteria Using the Analytical Hierarchical Process Tool. Resources, Conservation and Recycling, 86, 149-159. http://dx.doi.org/10.1016/j.resconrec.2014.03.002

[21] Orhon, D., Germirli, F. and Karahan, O. (2009) Management of Industrial Wastewaters. Industrial Wastewater Treatment by Activated Sludge, First. IWA Publishing, London, 400.

[22] Gozálvez-Zafrilla, J.M., Sanz-Escribano, D., Lora-García, J. and León Hidalgo, M.C. (2008) Nanofiltration of Secondary Effluent for Wastewater Reuse in the Textile Industry. Desalination, 222, 272-279. http://dx.doi.org/10.1016/j.desal.2007.01.173

[23] Abery, N.W., Sukadi, F., Budhiman, A.A., Kartamihardja, E.S. and Koeshendrajana, S. (2005) Fisheries and Cage Culture of Three Reservoirs in West Java, Indonesia, a Case Study of Ambitious Development and Resulting Interactions. Fisheries Management and Ecology, 12, 315-330. http://dx.doi.org/10.1111/j.1365-2400.2005.00455.x

[24] Murray, A. and Ray, I. (2010) Commentary: Back-End Users: The Unrecognized Stakeholders in Demand-Driven Sanitation. Journal of Planning Education and Research, 30, 94102. http://dx.doi.org/10.1177/0739456X10369800

[25] Kerstens, S.M., De Mes, T.Z.D. and Lue, B. (2009) Designing Sustainable Sanitation in Urban Planning Proposed for Changzhou, China. Water, Science and Technology, 60, 31653172. http://dx.doi.org/10.2166/wst.2009.160

[26] Aye, L. and Widjaya, E.R. (2006) Environmental and economic analyses of waste disposal options for traditional markets in Indonesia. Waste Management, 26, 1180-1191. http://dx.doi.org/10.1016/j.wasman.2005.09.010

[27] Aprilia, A., Tezuka, T. and Spaargaren, G. (2012) Household Solid Waste Management in Jakarta, Indonesia: A Socio-Economic Evaluation. In: Rebellon LFM, Ed., Waste Management-An Integrated Vision. InTech, Croatia, 30. http://dx.doi.org/10.5772/51464

[28] Nandy, B., Sharma, G., Garg, S., Kumari, S., George, T., Sunanda, Y., et al. (2015) Recovery 
of Consumer Waste in India-A Mass Flow Analysis for Paper, Plastic and Glass and the Contribution of Households and the Informal Sector. Resources, Conservation and Recycling, 101, 167-181. http://dx.doi.org/10.1016/j.resconrec.2015.05.012

[29] Kerstens, S.M., Priyanka, A., Van Dijk, K.C., De Ruijter, F.J., Leusbrock, I. and Zeeman, G. (2016) Potential Demand for Recoverable Resources from Indonesian Wastewater and Solid Waste. Resources, Conservation and Recycling, 110, 16-29. http://dx.doi.org/10.1016/j.resconrec.2016.03.002

[30] Alam, K. (2008) Cost-Benefit Analysis of Restoring Buriganga River, Bangladesh. International Journal of Water Resources Development, 24, 593-607. http://dx.doi.org/10.1080/07900620802224486

[31] Winara, A., Hutton, G., Oktarinda Purnomo, E., Hadiwardoyo, K., Merdykasari, I., et al. (2011) Economic Assessment of Sanitation Interventions in Indonesia. Jakarta, Indonesia.

[32] Hutton, G. (2013) Global Costs and Benefits of Reaching Universal Coverage of Sanitation and Drinking-Water Supply. Journal of Water and Health, 11, 1-12. http://dx.doi.org/10.2166/wh.2012.105

[33] Hutton, G., Rodriguez, U.-P., Winara, A., Anh, N.V., Phyrum, K., Chuan, L., et al. (2014) Economic Efficiency of Sanitation Interventions in Southeast Asia. Journal of Water, Sanitation and Hygiene for Development, 4, 23-26. http://dx.doi.org/10.2166/washdev.2013.158

[34] Ward, F.A. (2012) Cost-Benefit and Water Resources Policy: A Survey. Water Policy, 14, 250-280. http://dx.doi.org/10.2166/wp.2011.021

[35] Ng, B.J.H., Zhou, J., Giannis, A., Chang, V.W.-C. and Wang, J.-Y. (2014) Environmental Life Cycle Assessment of Different Domestic Wastewater Streams: Policy Effectiveness in a Tropical Urban Environment. Journal of Environmental Management, 140, 60-68. http://dx.doi.org/10.1016/j.jenvman.2014.01.052

[36] Malekpour, S., Langeveld, J., Letema, S., Clemens, F. and van Lier, J.B. (2013) Judgment under Uncertainty: A Probabilistic Evaluation Framework for Decision-Making about Sanitation Systems in Low-Income Countries. Journal of Environmental Management, 118, 106114. http://dx.doi.org/10.1016/j.jenvman.2013.01.007

[37] De Vries, D. (2012) BSc Thesis: Feasible Wastewater Treatment Technologies for Upper Citarum's Textile Companies. Wageningen University, Wageningen.

[38] Deltares (2009) RIBASIM River Basin Planning and Management Software Guide. Deltares, Delft, 4.

[39] BPLHD (2010) Water Quality Data for COD, BOD, N and P for the Period 2001-2009 in the Upper Citarum River at Different Locations from West Java Regional Control Agency of the Living Environment (BPLHD). Received as XLS Files as Part of the ADB's 6 Ci's Project TA7189.

[40] BPLHD West Java (2011) River Water Quality in Bandung in 2011 [Original Title in Indonesia: kualitas air sungai prioritas prokasih 2011]. Bandung.

[41] DKI (2005) Wastewater Management in Province DKI [Originally Title in Indonesian: Pengelolaan air limbah domestik di provinsi daerah khusus ibukota jakarta dengan]. Jakarta, Indonesia, 23.

[42] Bojong Soang (2012) Bojong Soang WWTP Access Data Obtained From a Visit to the Plant.

[43] ESDM (2009) Industrial Ground Water Abstraction Values (Base Year 2009) in the Upper Citarum River Area Obtained from the Energy and Mineral Resources Department (ESDM).

[44] PSDA (2010) Industrial Surface Water Abstraction Data (2010) Obtained Directly from the Provincial Agency for Water Resources Management (PSDA). 
[45] BPLHD (2010) Report of the Results of Self Monitoring Wastewater and Air Quality Activities in West Java. Environmental Pollution Monitoring Activities Fiscal Year 2010 [Original Title in Indonesia: Laporan hasil self monitoring limbah cair \& kualitas udara pada kegiat]. Bandung.

[46] KNLH (2010) Industry Monitoring Report Recommendations. Chapter II. Monitoring of Industrial Activity [Original Title in Indonesia: Laporan Rekomendasi Pemantauan Industri, BAB II. Pemantauan Kegiatan Industri]. Cimahi.

[47] BWRP (2000) Guidelines for Basin Water Resources Planning-Water Quality. Basin Water Resources Planning Project.

[48] Arantes, V. and Milagres, A.M.F. (2007) Application of Statistical Experimental Design to the Treatment of Bleaching Kraft Mill Effluent Using a Mediated Free Radical System. Water, Science and Technology, 55, 1-7. http://dx.doi.org/10.2166/wst.2007.205

[49] Pronk, M., de Kreuk, M.K., de Bruin, B., Kamminga, P., Kleerebezem, R. and van Loosdrecht, M.C.M. (2015) Full Scale Performance of the Aerobic Granular Sludge Process for Sewage Treatment. Water Research, 84, 207-217. http://dx.doi.org/10.1016/j.watres.2015.07.011

[50] Kerstens, S.M., Spiller, M., Leusbrock, I. and Zeeman, G. (2016) A New Approach to Nationwide Sanitation Planning for Developing Countries: Case Study of Indonesia. Science of the Total Environment, 550, 676-689. http://dx.doi.org/10.1016/j.scitotenv.2016.01.104

[51] MPS and Nijhuis (2012) Discussions with International Suppliers in Indonesia (MPS and Nijhuis) on Applicable WWTP for Textile Wastewater in Indonesia.

[52] Gonenc, I.E., Wolflin, J.P. and Russo, R.C. (2014) Sustainable Watershed Management. CRC Press, London. http://dx.doi.org/10.1201/b17433

[53] Kerstens, S.M., Hutton, G., Van Nes, A. and Firmansyah, I. (2013) Downstream Impacts of Water Pollution in the Upper Citarum River, West Java, Indonesia Economic Assessment of Interventions to Improve Water Quality. Jakarta, Indonesia.

[54] Waddington, H., Snilstveit, B., White, H. and Fewtrell, L. (2009) Water, Sanitation and Hygiene Interventions to Combat Childhood Diarrhoea in Developing Countries. The International Initiative for Impact Evaluation (3IE).

[55] Barreto, M.L., Genser, B., Strina, A., Teixeira, M.G., Assis, A.M.O., Rego, R.F., et al. (2010) Impact of a Citywide Sanitation Program in Northeast Brazil on Intestinal Parasites Infection in Young Children. Environmental Health Perspectives, 118, 1637-1642. http://dx.doi.org/10.1289/ehp.1002058

[56] Moraes, L.R.S., Cancio, J.A., Cairncross, S. and Huttly, S. (2003) Impact of Drainage and Sewerage on Diarrhoea in Poor Urban Areas in Salvador, Brazil. Transactions of the Royal Society of Tropical Medicine and Hygiene, 97, 153-158. http://dx.doi.org/10.1016/S0035-9203(03)90104-0

[57] Gwilliam, K.M. (1997) The Value of Time in Economic Evaluation of Transport Projects: Lessons from Recent Research. Washington DC, Report No. OT-5.

[58] WSP (2012) Interview with Field Officers of the Provincial Fishery Department of West Java Performed by WSP. Bandung.

[59] Ministry of Health (2010) Riset Kesehatan Dasar [Basic Health Research]. Jakarta, Indonesia.

[60] GoI (2001) Presidential Decree No 82, 2001 Water Quality Management and Water Pollution Control [Pengelolaan kualitas air dan pengendalian pencemaran air]. Government of Indonesia, Jakarta, Indonesia, 1-31.

[61] Alam, M.K. and Marinova, D. (2003) Measuring the Total Value of a River Cleanup. Water, 
Science and Technology, 48, 149-156.

[62] WSP (2011) Lessons in Urban Sanitation Indonesia Sanitation Sector Development: Indonesia Sanitation Sector Development Program 2006-2010. Jakarta, Indonesia.

[63] Winters, M.S., Karim, A.G. and Martawardaya, B. (2014) Public Service Provision under Conditions of Insufficient Citizen Demand: Insights from the Urban Sanitation Sector in Indonesia. World Development, 60, 31-42. http://dx.doi.org/10.1016/j.worlddev.2014.03.017

[64] Petit-Boix, A., Sanjuan-Delmás, D., Gasol, C.M., Villalba, G., Suárez-Ojeda, M.E., Gabarrell, X., et al. (2014) Environmental Assessment of Sewer Construction in Small to Medium Sized Cities Using Life Cycle Assessment. Water Resources Management, 28, 979-997. http://dx.doi.org/10.1007/s11269-014-0528-z

[65] Mirakyan, A. and De Guio, R. (2013) Integrated Energy Planning in Cities and Territories: A Review of Methods and Tools. Renewable and Sustainable Energy Reviews, 22, 289-297. http://dx.doi.org/10.1016/j.rser.2013.01.033

[66] Pollack, J. (2009) Multimethodology in Series and Parallel: Strategic Planning Using Hard and Soft OR. Journal of the Operational Research Society, 60, 156-167. http://dx.doi.org/10.1057/palgrave.jors.2602538

[67] Guest, J.S., Skerlos, S.J., Barnard, J.L., Beck, M.B., Daigger, G.T., Hilger, H., et al. (2009) A New Planning and Design Paradigm to Achieve Sustainable Resource Recovery from Wastewater. Environmental Science and Technology, 43, 6126-6130. http://dx.doi.org/10.1021/es9010515

[68] Chaerul, M., Fahruroji, A.R. and Fujiwara, T. (2013) Recycling of Plastic Packaging Waste in Bandung City, Indonesia. Journal of Material Cycles and Waste Management, 16, 509518. http://dx.doi.org/10.1007/s10163-013-0201-2

[69] Sasaki, S. and Araki, T. (2013) Employer-Employee and Buyer-Seller Relationships among Waste Pickers at Final Disposal Site in Informal Recycling: The Case of Bantar Gebang in Indonesia. Habitat International, 40, 51-57. http://dx.doi.org/10.1016/j.habitatint.2013.02.003

[70] WHO (2006) Guidelines for the Safe Use of Wastewater, Excreta and Greywater. Volume 1 Policy and Regulatory Aspects. WHO (World Health Organization) Press, Geneva, Switzerland.

[71] Reijnders, L. (2014) Phosphorus Resources, Their Depletion and Conservation: A Review. Resources, Conservation and Recycling, 93, 32-49. http://dx.doi.org/10.1016/j.resconrec.2014.09.006

[72] Zitomer, D.H., Adhikari, P., Heisel, C. and Dineen, D. (2008) Municipal Anaerobic Digesters for Codigestion, Energy Recovery, and Greenhouse Gas Reductions. Water Environment Research, 80, 229-237. http://dx.doi.org/10.2175/106143007X221201

[73] Spiller, M., Vreeburg, J.H.G., Leusbrock, I. and Zeeman, G. (2015) Flexible Design in Water and Wastewater Engineering-Definitions, Literature and Decision Guide. Journal of Environmental Management, 149, 271-281. http://dx.doi.org/10.1016/j.jenvman.2014.09.031

[74] ADB (2013) TA-7739 INO: Supporting Water Operators' Partnerships. Indonesia Water Supply and Sanitation Institute (IWWI) (44090-012), Jakarta, Indonesia.

[75] D'Hondt, L. (2013) Indonesia's Environmental Law of 2009 and Its Administrative Coercion Provisions. A Conceptual Misunderstanding with Large Practical Implications? SSRN (Social Science Research Network), Leiden, 1-7.

[76] Blackman, A. (2010) Alternative Pollution Control Policies in Developing Countries. Review of Environmental Economics and Policy, 4, 234-253. 
http://dx.doi.org/10.1093/reep/req005

[77] Rajeshwari, K., Balakrishnan, M., Kansal, A., Lata, K. and Kishore, V.V. (2000) State-of-theArt of Anaerobic Digestion Technology for Industrial Wastewater Treatment. Renewable and Sustainable Energy Reviews, 4, 135-156.

http://dx.doi.org/10.1016/S1364-0321(99)00014-3

[78] Van Lier, J.B. (2008) High-Rate Anaerobic Wastewater Treatment: Diversifying from Endof-the-Pipe Treatment to Resource-Oriented Conversion Techniques. Water, Science and Technology, 57, 1137-1148. http://dx.doi.org/10.2166/wst.2008.040

[79] Lasut, M.T., Jensen, K.R. and Shivakoti, G. (2008) Analysis of Constraints and Potentials for Wastewater Management in the Coastal City of Manado, North Sulawesi, Indonesia. Journal of Environmental Management, 88, 1141-1150. http://dx.doi.org/10.1016/j.jenvman.2007.06.011

[80] Day, B. and Mourato, S. (1998) Willingness to Pay for Water Quality Maintenance in Chinese Rivers. CSERGE Working Paper WM 98-02, London.

[81] Whittington, D., Jeuland, M., Barker, K. and Yuen, Y. (2012) Setting Priorities, Targeting Subsidies among Water, Sanitation, and Preventive Health Interventions in Developing Countries. World Development, 40, 1546-1468. http://dx.doi.org/10.1016/j.worlddev.2012.03.004

[82] McGranahan, G. (2015) Realizing the Right to Sanitation in Deprived Urban Communities: Meeting the Challenges of Collective Action, Coproduction, Affordability, and Housing Tenure. World Development, 68, 242-253.

http://dx.doi.org/10.1016/j.worlddev.2014.12.008

\section{Submit or recommend next manuscript to SCIRP and we will provide best service for you:}

Accepting pre-submission inquiries through Email, Facebook, LinkedIn, Twitter, etc. A wide selection of journals (inclusive of 9 subjects, more than 200 journals)

Providing 24-hour high-quality service

User-friendly online submission system

Fair and swift peer-review system

Efficient typesetting and proofreading procedure

Display of the result of downloads and visits, as well as the number of cited articles

Maximum dissemination of your research work

Submit your manuscript at: http://papersubmission.scirp.org/

Or contact jep@scirp.org 